then get out of that person's way." He retired from Auburn University as professor emeritus in 1980.

His primary teaching and research fields were in political theory, the legislative process, and politics and political parties. During his career, he published various monographs and articles in professional journals and coauthored with Dr. Robert B. Highsaw the first textbook on Mississippi state and local government. He also organized and conducted seminars for new members of the legislature and served as a consultant on a number of public policy issues in both Mississippi and Alabama.

At Auburn he created a new department of political science almost from scratch, inheriting a small number of four able faculty members who were transferred from the history department to the new unit in 1968 . By 1980 , when he retired, the department was composed of 20 academic positions, 16 of which were filled with political scientists holding the Ph.D. degree; and there were 341 students majoring in programs offered by the departmentthe largest number of majors, save one, of all the departments in Auburn's School of Arts and Sciences. At that time the department presented five separate curricular offerings: the major in political science through the general curriculum; a criminal justice curriculum; a public administration curriculum; a prehospital and health services administration curriculum; and a pre-law curriculum. A masters program was approved in September 1969. Plans begun in Nolan's administration culminated in the addition of a master of public administration and a Ph.D. in public administration and public policy after his retirement. By the time of his death in 1998 , the department had grown to 28 full-time professional positions, thanks in large part to the remarkable momentum provided by Nolan Fortenberry.

He was preceded in death by his second son, Joseph E. Fortenberry. $\mathrm{He}$ is survived by his wife, Mary Edwards Fortenberry, and his first son, Charles Nolan Fortenberry Jr. of Jackson, Mississippi. He is also sur- vived by Joe's wife, Ashley Doherty Fortenberry, and their daughter, Dorothy Ashley Fortenberry.

Just prior to his death, a former student established the HowertonFortenberry Award in the Study of Government as an endowed fund to honor his two senior professors at the University of Mississippi. Auburn University also established the Fortenberry Scholarship, College of Liberal Arts, at that institution. Donations may be made to either of these funds in his honor or to the Friends of the Library at the University of Mississippi.

Donald S. Vaughan University of Mississippi

\section{David T. Cattell}

David Cattell's retirement from the UCLA's department of political science in 1988, after a service of 36 years, most likely attracted little attention on campus, except from a handful of his close friends. This was because David was one of the most fiercely private persons I have known. Unlike many of his colleagues, he was not prone to engage in lengthy gossip sessions in the faculty center. He was also fiercely independent, as witnessed when, during his progressive illness, he refused his friends' help until he no longer could stand up and walk, and had to use a wheelchair. David's independence, his penchant for privacy, and his inability or unwillingness to suffer fools gladly were further fueled by a certain shyness that many who first met him took for hostility or indifference. This was a pity since, for the few of his real friends, David was truly a uniquely gifted person.

David was born in 1923 in Hinsdale, Illinois. He entered Amherst in 1941 but, like many of his generation, quit college and joined what was then called the U.S. Army Air Corps. In 1943 he was posted to the Fukien Province in China, where for the next three years he was in command of a weather reconnaissance base. He returned to Amherst in 1946 and graduated cum laude the following year with a B.A. in History.

In 1947 David made a decision that was to determine his academic and scholarly career for the next forty years. He enrolled at the newly established Russian Institute at Columbia, which pioneered a new subfield in political science known as Soviet studies, and which became a breeding ground for several generations of specialists in Soviet/Russian area studies. David caught the eye of Philip Mosely, director of the Institute and one of the early giants in the profession, who agreed to sponsor his doctoral dissertation, completed in 1953.

The dissertation, Communism and the Spanish Civil War, published in 1955 by the University of California Press, together with its companion volume, Soviet Diplomacy and the Spanish Civil War (University of California Press, 1957), turned out to be David's most significant scholarly accomplishment. Based on extensive archival research in England, Holland, and Spain, both books became minor classics and obligatory reading for graduate students and fellow scholars alike. Translated into Italian, they were reprinted by the Johnson Reprint Corporation in 1969.

David joined UCLA's department of political science in 1952 as an instructor, reaching full professor in 1966. He soon developed into one of the most effective undergraduate and graduate teachers in the department, as testified by unsolicited evaluations, especially from his graduate students who commented favorably on his commitment to excellence, the time he devoted to advising his students, and to his insistence on bringing out the best among his students. Many of the Ph.D. students he sponsored ended up at various universities around the country; one of them, Professor Edward Gonzalez, retired in 1994 after teaching political science for 28 years at UCLA. David also taught as an exchange professor in Leningrad (1966), Kampala, Uganda (1967), and Rio de Janeiro (1970).

From the outset, David devoted much effort and energy to university affairs, at both the campus and statewide levels. The highly laudatory letters from the President's Office in Berkeley and from chairmen of various Academic Senate 
committees at UCLA are among the most impressive testimonies to David's incessant efforts to raise the level of performance of academic self-governance throughout the system.

Not surprisingly, David's commitment to teaching and university and community service took a rather heavy toll on his research. Nonetheless, he remained in the mainstream of research on the Soviet Union. In the late 1960 s he began to focus on the critical issue of Soviet housing and urban affairs, and in 1968 he published Leningrad: $A$ Case Study of Soviet Urban Government (Praeger, 1968), which became a model study of its kind. This was followed by a series of articles on various aspects of Soviet housing policies. His interest in teaching was reflected in the publication of Comparative Politics: Institutions, Behavior and Development (Mayfield Publishing Company, 1978), coauthored with Richard Sisson. The Parkinson's disease, which began to affect him in the early 1980s, essentially ended his research. Still, he continued as editor of the well-known quarterly, Studies in Comparative Communism, which he had to relinquish for health reasons in 1990.

The above summary suffices to paint the picture of a devoted teacher, energetic Academic Senate committeeman, and a diligent researcher, but it says little of David as a highly cultured member of the UCLA community. As noted, this side of his character was less apparent except to his close friends.

What struck most of us was his generosity, which manifested itself in many ways: helping and advising his students, welcoming new faculty members, and giving much of himself to journal editing even when the state of his health made the last most onerous. It was David who was instrumental in bringing me to UCLA 35 years ago and in helping my family and me to settle down and feel at home. His last act of generosity took the form of a sizable grant to the political science department, which allowed it to establish a research fund for the junior faculty.

But there was more. For his intimate friends, David was, above all, a true gourmet-an excellent cook who delighted in preparing elaborate dishes from all over the world. Dinners at the Cattell's were true feasts, greatly enjoyed by those lucky enough to be invited. The dinners were accompanied by excellent vintage wines, as David was proud of maintaining a small but select cellar in his house in Pacific Palisades.

In addition to his culinary prowess, David had an eye for artistic excellence, and his house contained many find works of art, which he gladly displayed to his friends. By the time of his death, the collection, which he bequeathed to the UCLA Armand Hammer Museum, proved much more valuable than most of us would have expected.

Most of all, David will be fondly remembered by members of the Political Science Poker Group. For longer than we can recall, every first Thursday of each month seven of us would assemble-first in David's house in Pacific Palisades, then in his condominium in Santa Monica - to play poker, drink beer, eat cold cuts and gossip. Over the years, the membership of the group varied: some of its members died, some retired, others moved away. Yet new members were recruited and the group persisted until it could justly be called the longest floating poker game in Southern California-thanks, mostly, to David's hospitality.

David died in his sleep in San Jose on July 10 , 1998, due to complications from Parkinson's Disease. He is survived by a daughter, Jody, a son, Herbert, a sister, Ann Johnson, and his friends-all of who will miss him greatly.

\section{Andrzej Korbonski \\ University of California, Los Angeles}

\section{John D. Martz III}

John D. Martz III, distinguished professor of political science and former head of the department of political science at Penn State, died on August 16, at the age of 64. At the time of his death, he was in Caracas, Venezuela, directing crossnational research on the problems of governability and democratic consolidation.
A native of Latrobe, Pennsylvania, John was the only son of the late Col. John D. Martz Jr. and Margaret Sipe Martz. In 1983 he married Corazon Cruz. He received his A.B. from Harvard University, his A.M. from George Washington University, and his Ph.D. from the University of North Carolina, Chapel Hill. Before coming to Penn State in 1978, to head the department of political science, he served as an officer in Army intelligence and as chairman of the department of political Science at the University of North Carolina, Chapel Hill. Martz stepped down as department head to resume full-time research and teaching in 1985, and returned as interim department head during 1991-92.

When not writing books or teaching, John Martz immersed himself in classical music. His favorites included Schubert, Bach, and Gershwin. He was an accomplished violist with the Nittany Valley Symphony Orchestra and also played the piano. John enjoyed the company of dogs, and in his younger days showed his Russian Wolfhounds competitively. He took great pride in his Western Pennsylvania roots and his knowledge of regional folkways was legendary.

His research focused on political parties, transitions to democracy, and United States-Latin American relations. His prolific work drew heavily upon the experiences of Ecuador, Colombia, and Venezuela. John explored every angle of an issue, but his commitment to responsive government and human rights was unflagging. During an academic career that spanned more than thirty years, he held visiting academic appointments at universities in Quito, Bogota, and Caracas. He was a consultant to the Departments of State and Defense and to the National Intelligence Council. John Martz served as editor of the Latin American Research Review (197378 ), and at the time of his passing was editor of the highly respected Studies in Comparative International Development.

Students found John to be a knowledgeable, dedicated, and inspiring teacher. His finely honed 